\title{
Incubation of Fear Is Regulated by TIP39 Peptide Signaling in the Medial Nucleus of the Amygdala
}

\author{
Mumeko C. Tsuda, Ho-Man Yeung, Jonathan Kuo, and Ted B. Usdin \\ Section on Fundamental Neuroscience, National Institute of Mental Health, National Institutes of Health, Bethesda, Maryland 20892
}

Fear-related psychopathologies such as post-traumatic stress disorder are characterized by impaired extinction of fearful memories. Recent behavioral evidence suggests that the neuropeptide tuberoinfundibular peptide of 39 residues (TIP39), via its receptor, the parathyroid hormone 2 receptor (PTH2R), modulates fear memory. Here we examined the anatomical and cellular localization of TIP39 signaling that contributes to the increase in fear memory over time following a traumatic event, called fear memory incubation. Contextual freezing, a behavioral sign of fear memory, was significantly greater in PTH2R knock-out than wild-type male mice 2 and 4 weeks after a $2 \mathrm{~s} 1.5 \mathrm{~mA}$ footshock. PTH2R knock-out mice had significantly reduced c-Fos activation in the medial amygdala (MeA) following both footshock and fear recall, but had normal activation in the hypothalamic paraventricular nucleus and the amygdalar central nucleus compared with wild-type. We therefore investigated the contribution of MeA TIP39 signaling to fear incubation. Similar to the effect of global TIP39 signaling loss, blockade of TIP39 signaling in the MeA by lentivirus-mediated expression of a secreted PTH2R antagonist augmented fear incubation. Ablation of MeA PTH2R-expressing neurons also strengthened the fear incubation effect. Using the designer receptor exclusively activated by designer drug pharmacogenetic approach, transient inhibition of MeA PTH2R-expressing neurons before or immediately after the footshock, but not at the time of fear recall, enhanced fear incubation. Collectively, the findings demonstrate that TIP39 signaling within the MeA at the time of an aversive event regulates the increase over time in fear associated with the event context.

Key words: DREADD; fear enhancement; fear incubation; medial amygdala; neuropeptide; PTSD

\section{Significance Statement}

Fear-related psychopathologies such as post-traumatic stress disorder (PTSD) are characterized by excessive responses to traumaassociated cues. Fear responses can increase over time without additional cue exposure or stress. This work shows that modulatory processes within the medial nucleus of the amygdala near the time of a traumatic event influence the strength of fear responses that occur much later. The modulatory processes include signaling by the neuropeptide TIP39 and neurons that express its receptor. These findings will help in the understanding of why traumatic events sometimes have severe psychological consequences. One implication is that targeting neuromodulation in the medial amygdala could potentially help prevent development of PTSD.

\section{Introduction}

Fear-related psychopathologies, such as post-traumatic stress disorder (PTSD), remain a major therapeutic challenge despite significant recent progress in the understanding of circuits involved in fear memory (Herry and Johansen, 2014). PTSD symptoms include recurrent recollections of a trauma, avoidance of

\footnotetext{
Received May 4, 2015; revised July 24, 2015; accepted July 27, 2015.

Author contributions: M.C.T. and T.B.U. designed research; M.C.T. and H.-M.Y. performed research; M.C.T., J.K., and T.B.U. contributed unpublished reagents/analytic tools; M.C.T., H.-M.Y., and T.B.U. analyzed data; M.C.T. and T.B.U. wrote the paper.

This research was supported by the Intramural Research Program of the National Institute of Mental Health (ZIA-MH002685). Technical support was provided by Milan Rusnak and Brian Coleman.

The authors declare no competing financial interests.

Correspondence should be addressed to Ted B. Usdin, Section on Fundamental Neuroscience, National Institute of Mental Health, Building 35, Room 1B-215, 35 Convent Drive, Bethesda, MD 20892. E-mail: usdint@mail.nih.gov. DOI:10.1523/JNEUROSCI.1736-15.2015

Copyright $\odot 2015$ the authors $\quad 0270-6474 / 15 / 3512152-10 \$ 15.00 / 0$
}

trauma-related stimuli, hyperarousal, and generalized anxiety. Delayed-onset PTSD, defined by symptom onset at least 6 months after the traumatic event, is reported in 39\% of military and 15\% of civilian PTSD cases (Andrews et al., 2007). PTSD is often characterized by a time-dependent increase in fear responses to trauma-associated cues, a phenomenon described as fear incubation (McAllister and McAllister, 1967). Fear incubation can be studied in mice and rats (Siegmund and Wotjak, 2006; Pickens et al., 2009; Morrow et al., 2015). Siegmund and Wotjak (2007) showed that a single footshock generates hyperarousal, enhanced contextual fear responses, and generalized anxiety (Pamplona et al., 2011). Moreover, fear and avoidance behaviors increase from 1 to $28 \mathrm{~d}$ of incubation in this paradigm, suggesting that it can be used to gain a better understanding of the neuroanatomical and molecular bases of fear incubation and insight into mechanisms that underlie the phenomenon of delayedonset PTSD. 
We recently found that the neuropeptide tuberoinfundibular peptide of 39 residues (TIP39) modulates fear incubation. TIP39 is synthesized by neurons in the thalamic subparafascicular area and the pontine medial paralemniscal nucleus that project to brain areas enriched in its receptor, the parathyroid hormone 2 receptor (PTH2R; Dobolyi et al., 2003b, 2010; Faber et al., 2007). Functional studies suggest that the TIP39/PTH2R system modulates stress responses, anxiety, and emotional behaviors (LaBuda et al., 2004; Fegley et al., 2008; Palkovits et al., 2009; Coutellier and Usdin, 2011; Coutellier et al., 2011). Global deletion of TIP39 signaling in TIP39-KO and PTH2R-KO mice enhanced conditioned fear memory $14 \mathrm{~d}$ but not $6 \mathrm{~d}$ after a single footshock, indicating potentiation of fear incubation (Coutellier and Usdin, 2011).

The central and basolateral nuclei of the amygdala are key components in the neural circuitry of innate and learned fear (LeDoux, 2000; Marek et al., 2013), but little is known about the circuits that underlie fear incubation. The amygdala is likely to be involved, based on its contributions to fear memory. Recent observations suggest that the central amygdala (CeA) plays a critical role in a potentially related phenomenon, incubation of drug craving, which is a time-dependent increase in cue-induced drug-seeking behavior after withdrawal (Pickens et al., 2011; Li et al., 2015). Within the amygdala, PTH2R expression and projections from TIP39 neurons are relatively concentrated in the medial amygdala (MeA) and CeA (Faber et al., 2007). Neurons in the $\mathrm{MeA}$ are activated by contextual fear conditioning and lesions of the MeA disrupt several fear behaviors, including predator odor-evoked freezing, acute neuroendocrine responses, fear-potentiated startle, and conditioned fear memory (Milanovic et al., 1998; Walker et al., 2005; Müller and Fendt, 2006; Takahashi et al., 2007; Trogrlic et al., 2011; Cousens et al., 2012; Yoshida et al., 2014), suggesting that it may also be involved in fear memory. However, contributions of the MeA to either fear or drug-craving incubation have not yet been examined

In this study, we aimed to identify the anatomical and cellular bases for TIP39 modulation of fear incubation. First, we confirmed the enhanced fear incubation effect in PTH2R-KO mice and investigated whether it persists for 4 weeks. Second, we analyzed neuronal activation patterns following footshock and reexposure to the shock context to screen for brain regions involved in the fear incubation effects in PTH2R-KO mice. Next, we investigated the contribution of TIP39 signaling in the MeA to fear incubation by (1) blocking TIP39 signaling in the amygdala, (2) ablating PTH2R-expressing neurons in the MeA, or (3) transiently inhibiting their activity. The data suggest that TIP39 acts via PTH2Rs in the MeA to modulate fear incubation following a traumatic experience.

\section{Materials and Methods}

Animals. PTH2R-KO and WT male mice were derived from heterozygous breeding pairs. Development and genotyping of PTH2R-KO mice has been previously described (Dimitrov et al., 2010). C57BL/6J male mice were obtained from The Jackson Laboratory stock and bred on-site. A BAC transgenic line that expresses Cre recombinase in PTH2Rexpressing neurons (PTH2R-Cre) has been previously described (Dimitrov et al., 2013). All mice were 12-18 weeks old at the start of experiments and single housed in polycarbonate cages $(35.5 \times 14 \times 12.5$ $\mathrm{cm})$ at least 1 week before the start of behavioral testing. Mice were housed under a $12 \mathrm{~h}$ light/dark cycle (lights off at 8:00 h) with ad libitum access to food and water. All behavioral experiments were performed between 10:00 and 13:00 h. Experimental procedures were approved by the NIMH Animal Care and Use Committee and performed in accordance with the Institute for Laboratory Animal Research Guide for the Care and Use of Laboratory Animals.
Shock application and fear recall test. Shock application and recall tests were performed in a dimly lit (10 lux) $32 \times 36 \times 21 \mathrm{~cm}$ chamber with transparent walls and a metal grid floor for shock application located in a sound-attenuating cabinet (Med Associates). For shock application, after a $198 \mathrm{~s}$ acclimation period to the chamber, a single $2 \mathrm{~s}$ scrambled footshock of $1.5 \mathrm{~mA}$ was administered via the metal grid. The animals remained in the chamber for an additional $60 \mathrm{~s}$ before being returned to their home cage. Control mice were placed in the chamber for the same duration without receiving a shock. For fear recall tests, animals were returned to the shock chamber for $180 \mathrm{~s}$ and then returned to their home cage. Presentation of footshock and video recording was controlled by FreezeScan software (CleverSys). Freezing behavior, defined as immobility except for respiration movement, was manually scored off-line by an experimenter blind to the animals' experimental condition. Chambers were wiped clean with $70 \%$ ethanol between trials.

Extinction training. Shock application and recall tests were performed as described above. To evaluate effects of extinction training on fear incubation, WT and PTH2R-KO shocked mice were returned to the shock context for 30 min each day (extinction group) for 3 consecutive days starting $24 \mathrm{~h}$ after footshock exposure. Mice designated as the control group remained undisturbed in their home cage during these $3 \mathrm{~d}$.

Light/dark box transition test. The light/dark box transition test measured anxiety-related behaviors in shocked WT and PTH2R-KO mice $3 \mathrm{~d}$ after fear recall tests. The apparatus consisted of a dark compartment $(40 \times 13 \times 16 \mathrm{~cm})$ connected to a light compartment $(40 \times 27 \times 30 \mathrm{~cm})$ with an $8 \times 13 \mathrm{~cm}$ doorway. At the start of the experiment, mice were placed in the dark box of the apparatus and allowed to explore the apparatus for $10 \mathrm{~min}$. All tests were video recorded with a camera mounted above the apparatus and analyzed off-line using TopScan tracking software (CleverSys). The time spent in the light compartment was measured as an index of anxiety levels.

Forced swim test. The forced swim test measured depression-like behaviors in shocked WT and PTH2R-KO mice $4 \mathrm{~d}$ after fear recall tests. Clear Plexiglas cylinders ( $20 \mathrm{~cm}$ diameter) were filled with $20 \mathrm{~cm}$ of water $\left(24-25^{\circ} \mathrm{C}\right)$. Mice were placed in the cylinder for a total of $6 \mathrm{~min}$. All sessions were video recorded and the time spent immobile during the last 4 min of the test was manually scored off-line. Immobility was defined as motionless floating or only movements necessary to keep their head above water for breathing.

Evaluation of c-Fos expression after footshock and recall testing. PTH2R-KO and WT mice were assigned to either shocked or nonshocked (control) groups. Mice in one cohort of control and shocked PTH2R-KO and WT mice were killed 90 min after shock application (post shock). The second cohort of control and shocked PTH2R-KO and WT mice were killed 90 min after fear recall testing $28 \mathrm{~d}$ after shock exposure (post recall).

Adrenalectomy. Mice were anesthetized using isoflurane inhalation and the adrenal glands were removed bilaterally through a dorsal midline incision and lateral retroperitoneal incisions. Following surgery, skin incisions were closed with sterile wound clips and analgesia (ketoprofen, $5 \mathrm{mg} / \mathrm{kg}$, i.p.) was provided for $72 \mathrm{~h}$. Starting immediately after surgery, the drinking water was replaced with either $0.9 \%$ saline or $0.9 \%$ saline containing a low dose of corticosterone $(25 \mu \mathrm{g} / \mathrm{ml}$ with $0.15 \%$ ethanol; Sigma). Behavioral testing started 2 weeks after surgery.

Corticosterone assay. Blood samples were obtained from (1) PTH2R-KO and WT mice used for the c-Fos experiment before anesthesia for fixative perfusion and (2) PTH2R-KO and WT adrenalectomized mice after experiment completion by puncturing the submandibular vein using a mouse-bleeding lancet (Goldenrod Animal Lancet, $5 \mathrm{~mm}$; MEDIpoint). Blood was collected in EDTA-coated tubes (Microvette CB300 K2E; Sarstedt) and centrifuged at $2000 \mathrm{rpm}$ for $15 \mathrm{~min}$. Plasma was collected and frozen at $-20^{\circ} \mathrm{C}$. Corticosterone levels were determined using an Enzyme Immunoassay kit (ADI-901-097; Enzo Life Sciences). All samples in each experiment were processed together according to the manufacturer's protocol. Sensitivity of the assay was $26.99 \mathrm{pg} / \mathrm{ml}$.

Viruses. Lenti-HYWH - a lentivirus construct that expresses a secreted form of histidine ${ }^{4}$, tyrosine ${ }^{5}$, tryptophan $^{6}$, histidine ${ }^{7}$-TIP39 (HYWHTIP39), a PTH2R antagonist (Kuo and Usdin, 2007), plus cytoplasmic GFP and a control lentivirus that expresses GFP only (lenti-GFP) were 


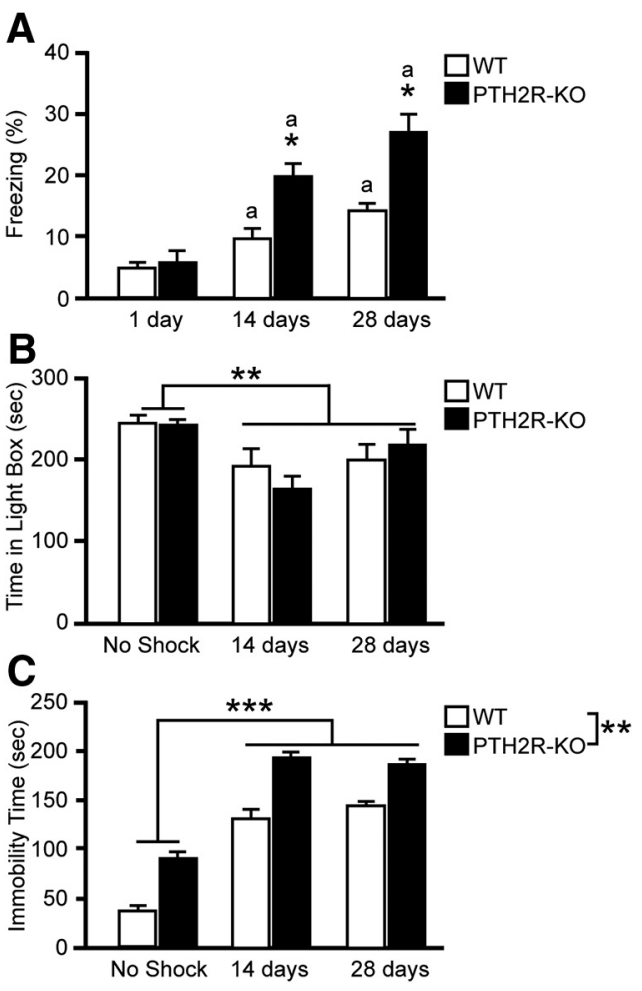

Figure 1. Evaluation of freezing, anxiety-like, and depression-like behaviors in WT and PTH2R-KO male mice after footshock. $A$, Percentage of time spent freezing in the shock context during fear recall testing $1 \mathrm{~d}, 14 \mathrm{~d}$, or $28 \mathrm{~d}$ after shock application. $\boldsymbol{B}$, Time spent in the light compartment during the light/dark box transition test was measured as an index of anxiety-like behavior. Mice were tested $3 \mathrm{~d}$ after fear recall testing. C, Immobility duration was measured in the forced swim test as an index of depression-like behavior. Mice were tested $4 \mathrm{~d}$ after fear recall. Nonshocked mice were included for baseline evaluation of anxiety- and depressionrelated behaviors. These mice were tested alongside the $14 \mathrm{~d}$ group. Nonshocked control: WT, $n=8$, PTH2R-KO, $n=7 ; 1 \mathrm{~d}$ after shock: WT, $n=7$, PTH2R-K0, $n=6 ; 14 \mathrm{~d}$ after shock: WT, $n=9$, PTH2R-K0, $n=9 ; 28 \mathrm{~d}$ after shock: WT, $n=10$, PTH2R-KO, $n=10$. ${ }^{*} p<0.01$ versus WT of same time point; ${ }^{a} p<0.05$ versus $1 \mathrm{~d}$ after shock of same genotype; ${ }^{* *} p<0.01$ and ${ }^{* * *} p<0.001$

described previously (Dimitrov et al., 2013). AAV2/9.flex-arch (encoding Cre recombinase-dependent expression of archaerhodopsin-GFP fusion) was obtained from the University of Pennsylvania Viral Vector Core Facility. AAV2.DTR (serotype 8), encoding Cre recombinasedependent expression of the human diphtheria toxin receptor (DTR), was produced as previously described (Dimitrov et al., 2013). AAV-DIOhM4Di (rAAV/hsyn-DIO-HA-hM4Di-IRES-mCitrine, serotype 5; Krashes et al., 2011) encoding Cre recombinase-dependent hM4Di was obtained from the University of North Carolina Vector Core Facility.

Stereotaxic surgery. Mice were anesthetized with isoflurane inhalation and placed in a stereotaxic frame. A $10 \mu \mathrm{l}$ Hamilton syringe was used to bilaterally inject $0.5 \mu \mathrm{l}$ of AAV-DIO-hM4Di, AAV2.DTR, AAV2/9.flexarch, lenti-HYWH, or lenti-GFP into target brain regions using a microsyringe pump controller (World Precision Instruments) at a speed of $50 \mathrm{nl}$ per min. The syringe was left in place for an additional $5 \mathrm{~min}$ after infusion to minimize backflow. Target brain regions were the MeA (anteroposterior $-1.5 \mathrm{~mm}$, mediolateral $\pm 2.2 \mathrm{~mm}$, dorsoventral $-5.7 \mathrm{~mm}$ ) and the CeA (anteroposterior $-1.2 \mathrm{~mm}$, mediolateral $\pm 2.4 \mathrm{~mm}$, dorsoventral $-5.0 \mathrm{~mm}$ ). Coordinates were determined using the Mouse Brain in Stereotaxic Coordinates (Paxinos and Franklin, 2008). Behavioral tests were conducted at least 4 weeks after stereotaxic injections.

Drugs and administration. For the PTH2R neuron ablation experiment, diphtheria toxin (500 ng/0.1 ml dissolved in saline; Sigma) was intraperitoneally administered every other day for a total of five injections starting 3 weeks after AAV2.DTR injection. Control mice were injected with saline.
Table 1. Freezing behavior following footshock and during fear recall in WT and PTH2R-KO male mice

\begin{tabular}{llc}
\hline & Post shock & Post recall \\
\hline $\begin{array}{l}\text { Freezing in recall test 28 d after shock } \\
\text { WT }\end{array}$ & & \\
$\quad$ Control & $\mathrm{N} / \mathrm{A}$ & $0.10 \% \pm 0.08$ \\
$\quad$ Shock & $\mathrm{N} / \mathrm{A}$ & $9.63 \% \pm 1.89$ \\
$\quad$ PTH2R-K0 & $\mathrm{N} / \mathrm{A}$ & \\
$\quad$ Control & $\mathrm{N} / \mathrm{A}$ & $0.01 \% \pm 0.01$ \\
$\quad$ Shock & & $16.42 \% \pm 2.24^{*}$ \\
Freezing 60 s after shock & & \\
WT & & \\
$\quad$ Control & $0.00 \% \pm 0.00$ & $0.00 \% \pm 0.00$ \\
$\quad$ Shock & $2.07 \% \pm 0.58$ & $0.26 \% \pm 0.18$ \\
PTH2R-K0 & & \\
$\quad$ Control & $0.02 \% \pm 0.02$ & $0.00 \% \pm 0.00$ \\
Shock & $0.82 \% \pm 0.37$ & $0.42 \% \pm 0.17$ \\
\hline
\end{tabular}

Percentage of time spent freezing in the shock context during fear recall testing $28 \mathrm{~d}$ after shock or $60 \mathrm{~s}$ after receiving a shock. Nonshocked (control) and shocked WT and PTH2R-KO mice were from postshock and postrecal groups used for the evaluation of $c-$ Fos expression. ${ }^{*} p<0.05$ versus shocked WT at the same time point. N/A, no available.

To transiently inhibit PTH2R-expressing neurons, AAV-DIOhM4Di-injected mice were intraperitoneally injected with clozapine $\mathrm{N}$-oxide (CNO; Sigma) either $1 \mathrm{~h}$ before or immediately after testing. CNO was dissolved in saline with $0.5 \%$ DMSO to a final concentration of $0.1 \mathrm{mg} / \mathrm{ml}$. The administered dose was $0.3 \mathrm{mg} / \mathrm{kg}$. Control animals were injected with saline.

Immunohistochemistry. All mice were deeply anesthetized and transcardially perfused with saline and then $4 \%$ paraformaldehyde. Brains were removed, postfixed overnight in $4 \%$ paraformaldehyde at $4^{\circ} \mathrm{C}$, immersed in $30 \%$ sucrose for $48 \mathrm{~h}$ at $4^{\circ} \mathrm{C}$, and then frozen. Brain areas of interest were sectioned on a sliding microtome at $30 \mu \mathrm{m}$. Free-floating sections were washed with $0.1 \mathrm{M}$ PBS, incubated in $3 \% \mathrm{H}_{2} \mathrm{O}_{2}$ in PBS for 15 min, and then blocked with $3 \%$ bovine serum albumin with $0.2 \%$ Triton $\mathrm{X}-100$ in PBS for $2 \mathrm{~h}$ at room temperature. Sections were then incubated with rabbit antibodies directed at GFP (1:10,000; ab290; Abcam), c-Fos (1:20,000; ab5; Calbiochem), or PTH2R (1:8000; Faber et al., 2007) for $48 \mathrm{~h}$ at $4^{\circ} \mathrm{C}$. Then, sections were incubated with a biotinylated goat antirabbit $\operatorname{IgG}$ (1:2000; Jackson ImmunoResearch) for $4-5 \mathrm{~h}$, followed by avidin-peroxidase complex (1:500; Vectastain Elite; Vector Laboratories) for $1-2 \mathrm{~h}$ at room temperature. Sections were visualized with either DyLight 488 or DyLight 594-conjugated tyramide prepared as previously described (Hopman et al., 1998). All sections were mounted onto gelatin-subbed slides and coverslipped with $2.5 \%$ PVA-DAPCO anti-fading medium.

Image acquisition and processing. Brain sections were matched according to the Paxinos and Franklin mouse brain atlas (Paxinos and Franklin, 2008). Images of fluorescent c-Fos-positive cells were captured using a $10 \times$ objective on a Zeiss Axioplan2 microscope equipped with an AxioCam HR camera and AxioVision software. Before counting c-Fospositive cells, color values of the images were inverted without altering the distribution of gray values to provide optimal visualization of labeled cells so that light areas appear dark. All c-Fos-positive cells were counted in outlined areas of the left and right side of nine hypothalamic paraventricular nucleus (PVN; bregma -0.23 to -1.23 ), six CeA (bregma -1.07 to -1.67 ), and $11 \mathrm{MeA}$ (bregma -0.95 to -2.15 ) sections for each mouse. Cell counts were totaled for each brain region and data were then converted and presented as percentage change from WT control to combine data from groups processed for immunohistochemistry at different times. This percentage was calculated using the following equation within postshock or postrecall time points for each brain region: percentage change $=[($ total number of c-Fos-positive cells for a given mouse $) /$ (mean c-Fos-positive number of WT control group) ] * 100 .

Images for GFP labeling of the AAV2/9.flex-arch were captured on an Olympus IX-70 microscope equipped with a X-Cite illuminator (Lumen Dynamics Group) and a CoolSNAP FX camera (Photometrics) using IPLab software (Scanalytics). Fluorescent immunolabeling of GFP (AAV-DIO-hM4Di and lenti-HYWH) and PTH2R (AAV2.DTR) was 


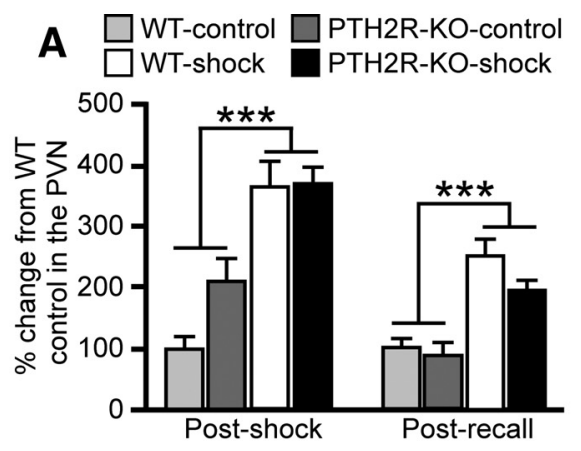

B

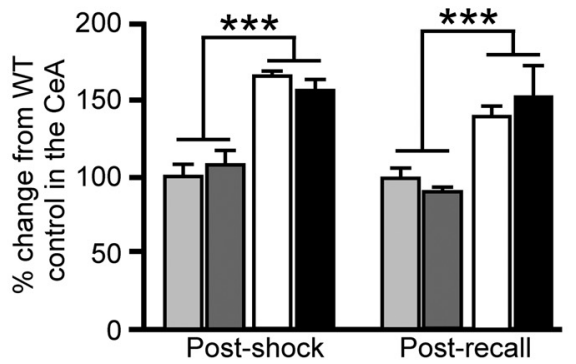

C
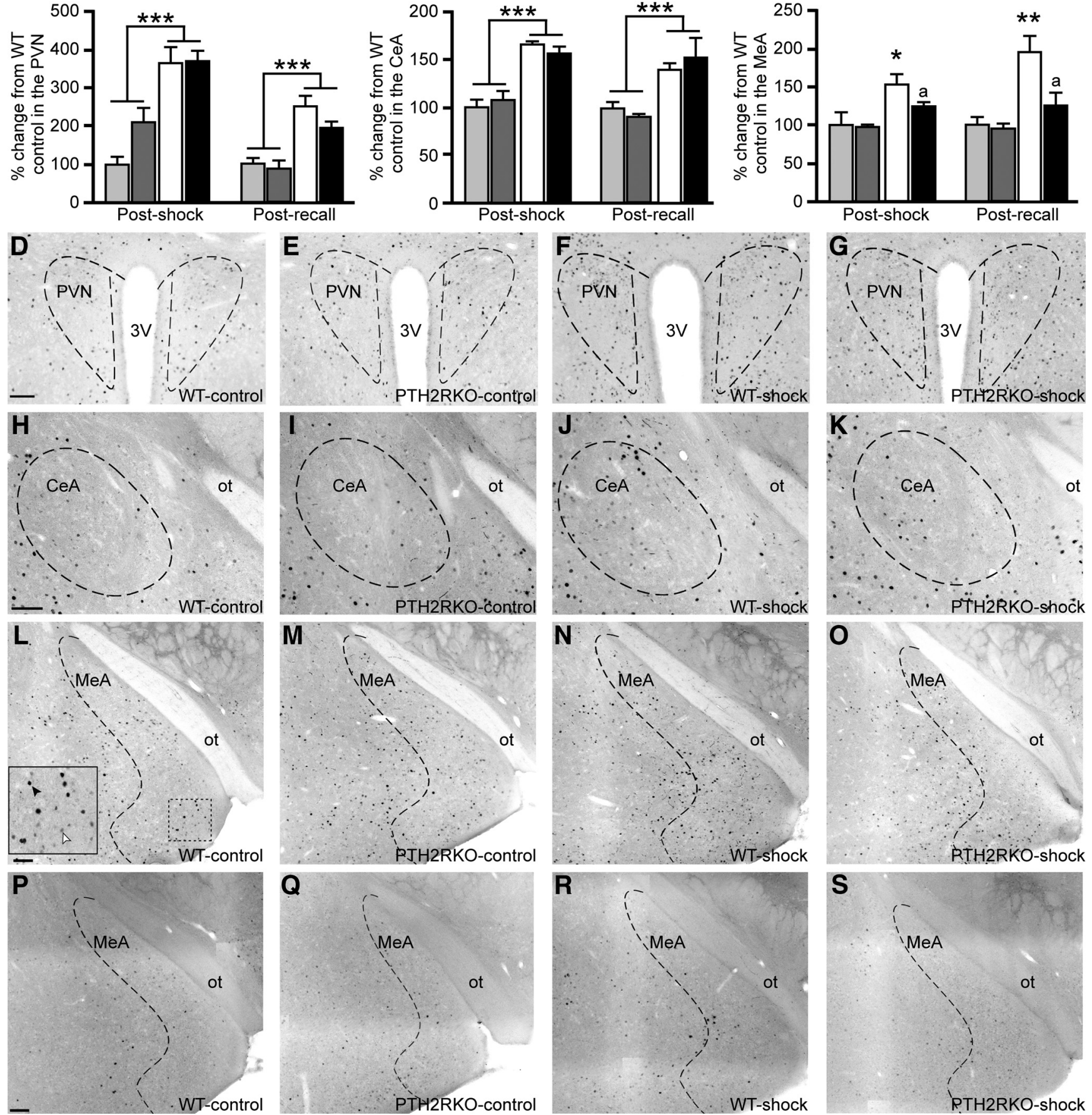

Figure 2. Evaluation of c-Fos induction following footshock or fear recall in WT and PTH2R-KO male mice. Cell counts in the PVN $(\boldsymbol{A})$, CeA $(\boldsymbol{B})$, and MeA $(\boldsymbol{C})$ are presented as the percentage of the WT control at each time point. Animals were killed 90 min following shock or recall testing. Representative images of c-Fos expression in control (nonshocked) and shocked PTH2R-K0 and WT from animals in the group killed 90 min following shock for the PVN $(\boldsymbol{D}-\boldsymbol{G})$, for the CeA $(\boldsymbol{H}-\boldsymbol{K})$, and for the MeA $(\boldsymbol{L}-\boldsymbol{0})$. The inset in $\boldsymbol{L}$ shows a high-power view of $\mathbf{c}-$ Fos-immunopositive cells. The cells indicated by the black and white arrowheads represent the darkest and lightest labeled cells that were considered as immunopositive during cell counting. $\boldsymbol{P}-\boldsymbol{S}$, Representative images from the MeA of animals killed $90 \mathrm{~min}$ after recall testing $28 \mathrm{~d}$ after footshock are presented. Outlines bordering the PVN, CeA, and MeA brain regions indicate the area in which counting was performed. Average number of c-Fos-positive cells for control WT groups is as follows: postshock PVN, 107.71 \pm 23.09 ; postrecall PVN, $137.38 \pm 23.51$; postshock CeA, $175.33 \pm 15.39$; postrecall CeA, 134.67 \pm 9.61 ; postshock MeA, $982.00 \pm 169.00$; and postrecall MeA, $284.20 \pm 28.86$. Scale bars: D-S, $100 \mu \mathrm{m}$. Post shock: WT, $n=13$, PTH2R-KO, $n=13$, Post recall: WT, $n=18$, PTH2R-KO, $n=19$. ${ }^{*} p<$ 0.05 and $^{* *} p<0.01$ versus control of same genotype at the same time point; ${ }^{a} p<0.05$ versus WT shocked at the same time point; ${ }^{* * *} p<0.001 .0 \mathrm{t}, 0$ optic tract; $3 \mathrm{~V}$, third ventricle.

detected using a Zeiss LSM780 confocal microscope. Final images were cropped and contrast adjusted using the levels command in Adobe Photoshop with no manipulation of individual image elements. Identical manipulations were performed on images that were compared with each other.
Statistics. Fear recall, light/dark box transition test, forced swim test data from fear incubation experiments, fear recall freezing data of mice that underwent extinction training, percentage change of c-Fos expression, and corticosterone data were analyzed by a two-way ANOVA for main effects of genotype, time/treatment, and their interactions. Freez- 
ing percentage measured during the $3 \mathrm{~d}$ of extinction training was analyzed by a two-way repeated-measures ANOVA for main effects of genotype, time, and their interactions. One-way ANOVA was used for four group comparisons in the freezing percentage $60 \mathrm{~s}$ after shock and at fear recall test in postshock and postrecall groups independently in the c-Fos experiment. Adrenalectomized WT and PTH2R-KO mice treated with either saline or corticosterone in saline in their drinking water were independent groups. Therefore fear recall data were analyzed using the Student's $t$ test to assess for genotype differences in each treatment. In lenti-HYWH and AAV2.DTR experiments, fear recall freezing responses were analyzed by a Student's $t$ test to examine treatment differences. Either a two-way ANOVA with repeated measures for treatment and time interactions or Student's $t$ test for treatment differences was used to analyze fear recall data of PTH2R-cre mice injected with AAV-DIOhM4Di in the MeA or CeA. Significant ANOVAs were followed by the Bonferroni post hoc test. Data are presented as mean \pm SEM. All data analyses were performed using Prism 5 software (GraphPad Software).

\section{Results}

Augmented fear incubation in mice that lack TIP39 signaling We evaluated fear recall in separate groups of PTH2R-KO and WT male mice 1,14 , and $28 \mathrm{~d}$ after footshock by measuring freezing behavior when they were returned to the context in which they received the shock (Fig. 1A). The freezing response increased over time in mice of both genotypes (two-way ANOVA, $F_{\text {time }(2,45)}=26.13, p<0.0001 ; n=6-10$ per group). PTH2R-KO mice froze significantly more than WT mice both $14 \mathrm{~d}$ (260\% vs $103 \%$ of baseline) and $28 \mathrm{~d}$ (394\% vs 199\%) after the footshock (two-way ANOVA, $F_{\text {genotype }} \times$ time $(2,45)=4.27, p=$ 0.020 , Bonferroni post hoc test, $p<0.01)$. To control for the possibility that a difference in spontaneous freezing contributed to this result, we exposed another group of WT and PTH2R-KO mice to the same context without applying shock. Both WT and PTH2R-KO mice in this group had very low freezing behavior when they were re-exposed to the context $28 \mathrm{~d}$ later (WT, $0.10 \pm$ $0.08 \%$; PTH2R-KO, $0.01 \pm 0.01 \%$ ).

Having observed a greater incubation effect on fear behavior in mice without TIP39 signaling than WT, we evaluated the effect of post footshock incubation time on anxiety- and depressionrelated behaviors. In the light/dark transition test, there was a main effect of time point, but no effect of genotype on the time spent in the light box. (Fig. $1 B$; two-way ANOVA, $F_{\text {time }(2,47)}=$ 5.88, $p=0.005 ; F_{\text {genotype }(1,47)}=0.09, p=0.771 ; n=6-10$ per group). Similarly, both shocked groups of WT and PTH2R-KO mice had increased immobility duration in the forced swim test compared with nonshocked control mice (Fig. 1C; two-way ANOVA, $F_{\text {time }(2,47)}=95.00, p<0.0001 ; n=6-10$ per group). In this case, there was a significant difference in immobility duration between WT and PTH2R-KO mice (two-way ANOVA, $\left.F_{\text {genotype(1,47) }}=69.97, p<0.0001\right)$. However, this difference was also observed in control PTH2R-KO and WT mice that were not shocked and in this test there was not a significant interaction between genotype and the postshock time point (two-way ANOVA, $\left.F_{\text {genotype }} \times \operatorname{time}(2,47)=1.05, p=0.359\right)$. Thus there was no difference in anxiety-related behaviors between PTH2R-KO and WT mice after footshock and a difference in depressionrelated behaviors appears to be explained by a genotype difference that is independent of the effects of footshock.

Enhanced fear incubation in PTH2R-KO mice is associated with a distinct neuronal activation pattern in the MeA To screen for brain regions that might underlie fear incubation effects in mice without TIP39 signaling, we looked at the pattern of neuronal activation following footshock and following fear
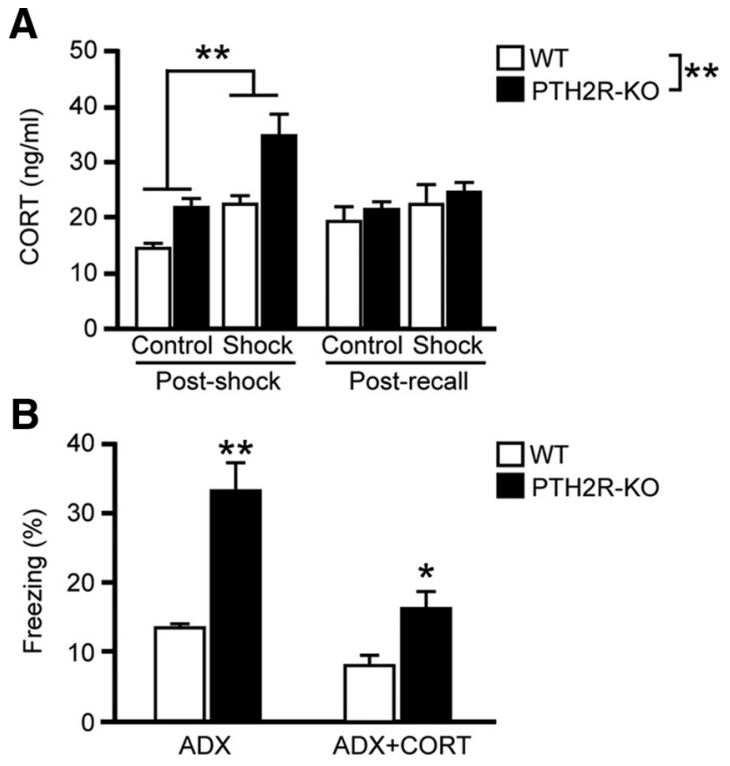

Figure 3. Contribution of HPA axis activation to fear incubation in PTH2R-KO mice. A, Corticosterone levels measured 90 min following footshock or following recall testing in WT and PTH2R-KO mice used to evaluate c-Fos expression. $\boldsymbol{B}$, Evaluation of fear recall following ADX in WT and PTH2R-KO mice. Recall testing was performed $28 \mathrm{~d}$ after footshock in mice that had either very low (ADX) or a fixed level of serum corticosterone (ADX + CORT). Plasma corticosterone in the ADX group was $5.14 \pm 1.03 \mathrm{ng} / \mathrm{ml}$ and in the $A D X+C O R T$ group it was $31.30 \pm$ $4.81 \mathrm{ng} / \mathrm{ml}$. Post shock: WT, $n=15$, PTH2R-KO, $n=14$; Post recall: WT, $n=20$, PTH2R-K0, $n=21$. ADX: WT, $n=5$, PTH2R-K0, $n=5$; ADX + CORT: WT, $n=8$, PTH2R-K0, $n=9 .{ }^{*} p<$ 0.05 and ${ }^{* *} p<0.01$ versus WT of same treatment group; ${ }^{* *} p<0.01$.

recall, using the immediate early gene c-Fos. First, using a new group of male mice, we confirmed the observation of an increased freezing response during recall testing $28 \mathrm{~d}$ after footshock in PTH2R-KO mice compared with shocked WT (Table 1; one-way ANOVA, $F_{(3,37)}=24.28, p<0.0001 ; n=8-11$ per group). Both PTH2R-KO and WT mice had low levels of freezing immediately after the footshock, suggesting similar direct responses to the shock (Table 1). We counted the number of c-Fospositive cells in the PVN, CeA, and MeA regions in one group of PTH2R-KO and WT mice 90 min after footshock and in a second group $90 \mathrm{~min}$ after recall testing (Fig. $2 A-S$ ). There was a robust increase in the number of c-Fos-positive cells in both PTH2R-KO and WT mice following shock and also following recall testing in the PVN (Fig. 2A,D-G) and CeA (Fig. 2 $B, H-K$ ) compared with their respective nonshocked control mice (two-way ANOVA; post shock, PVN: $F_{\text {treatment }(1,22)}=39.08, p<0.0001$; CeA: $F_{\text {treatment }(1,16)}=$ $33.55, p<0.0001 ; n=5-7$ per group; post recall, PVN: $F_{\text {treatment }(1,33)}=31.34, p<0.0001 ;$ CeA: $F_{\text {treatment }(1,18)}=29.06$, $p<0.001 ; n=5-11$ per group). However, there were no differences in c-Fos induction between WT and PTH2R-KO mice in the PVN and CeA. The number of c-Fos-positive cells in the MeA was greatly increased following shock and following recall testing only in shocked WT mice compared with control WT mice (Fig. $2 C, L-S$; two-way ANOVA, post shock, $F_{\text {genotype }} \times$ treatment $(1,15)=$ $3.70, p=0.073 ; n=4-5$ per group; post recall, $F_{\text {genotype }} \times$ treatment $(1,17)=$ $4.74, p=0.043 ; n=4-6$ per group; Bonferroni post hoc test, $p<$ 0.05 for both post shock and post recall). In contrast to WT mice, c-Fos expression did not increase in the MeA of shocked PTH2R-KO mice either following footshock or following footshock recall. Thus a larger fear incubation effect in mice that lack TIP39 signaling appears to be associated with impaired c-Fos activation in the MeA. 

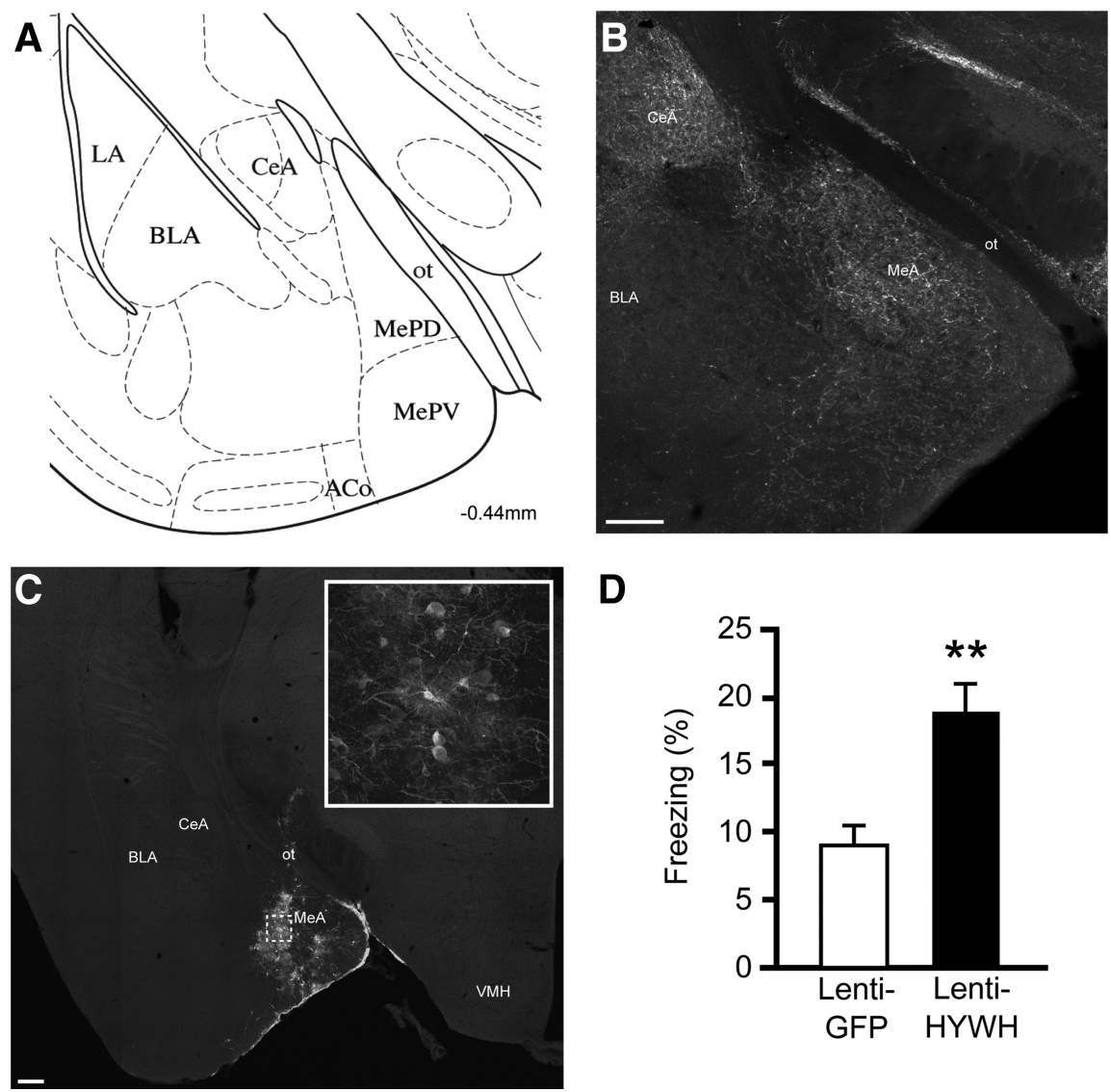

Figure 4. Blockade of TIP39 signaling in the amygdala enhances fear incubation. $A$, Diagram illustrating the approximate shape of the medial, central, and basolateral nuclei of the amygdala. $\boldsymbol{B}$, Immunolabeling of the PTH2R shows dense immunopositive fibers in the MeA and CeA. C, The amygdalar injection site of a WT mouse bilaterally injected with lenti-HYWH virus encoding a secreted PTH2R antagonist that also expresses GFP. Inset, high-power view. $\boldsymbol{D}$, Freezing responses measured during fear recall $28 \mathrm{~d}$ afterfootshock in lenti-GFP and lenti-HYWH-injected mice. Scale bars: $B, C, 200 \mu \mathrm{m}$. Lenti-GFP, $n=9$; Lenti-HYWH, $n=8 .{ }^{* *} p<$ 0.01 versus lenti-GFP. LA, lateral amygdala; BLA, basolateral amygdala; $A C 0$, anterior cortical amygdaloid nucleus; MePD, posterodorsal part of MeA; MePV, posteroventral part of MeA; VMH, ventromedial nucleus of the hypothalamus; ot, optic tract.

Differential hypothalamic-pituitary-adrenal axis activation is not responsible for the enhanced fear incubation of PTH2RKO mice

Blood corticosterone levels were increased after footshock, indicating activation of the hypothalamic-pituitary-adrenal (HPA) axis (Fig. 3A; two-way ANOVA, $F_{\text {treatment }(1,26)}=12.73, p=0.001 ; n=5-10$ per group). The corticosterone levels of both control and shocked PTH2R-KO mice were higher than similarly treated WT mice $\left(F_{\text {genotype }(1,26)}=11.61, p=0.002\right)$. However, the relative increase over the baseline level was very similar in shocked WT (154\%) and PTH2R-KO (158\%) mice $\left(F_{\text {genotype }} \times\right.$ treatment $(1,26)=0.15$, $p=0.703)$. Recall testing did not significantly increase the corticosterone level in any of the mouse groups. To ask whether changes in HPA axis function that were not detected by the measures of corticosterone made at single time points could explain the enhanced fear memory of PTH2R-KO mice, we examined fear memory in mice that had either a very low or a fixed level of serum corticosterone. We adrenalectomized (ADX) WT and PTH2R-KO mice 2 weeks before footshock delivery and provided one group with a fixed concentration of corticosterone by adding it to their drinking water. The enhanced fear memory of PTH2R-KO mice was preserved during recall testing $28 \mathrm{~d}$ after footshock in mice with either a fixed dose of delivered or a very low endogenous level of corticosterone (Fig. $3 B$; Student's $t$ test,
ADX: $T_{(8)}=4.75, p=0.001 ; \operatorname{ADX}+$ CORT: $T_{(15)}=2.49, p=0.025 ; n=5-9$ per group).

Blockade of amygdalar TIP39 signaling enhances fear incubation

Antibody labeling shows that PTH2Rs are present on fibers and/or terminals throughout the MeA and the adjacent CeA (Fig. $4 A, B$ ). Cell bodies are poorly detected with the PTH2R antibody in mice, but we have previously shown that PTH2R-expressing cells are relatively abundant in the mouse MeA by examining the distribution of $\beta$-galactosidase in a lacZ knockin mouse line and PTH2R mRNA by in situ hybridization (Faber et al., 2007). To evaluate whether the loss of TIP39 signaling in the medial region of the amygdala could underlie enhanced fear incubation in the PTH2R-KO mice, we injected a lentivirus that encodes a secreted PTH2R antagonist (lenti-HYWH) into WT male mice. We targeted the MeA area bilaterally with lenti-HYWH, which also expresses GFP, or with a similar virus that only expresses GFP (lenti-GFP; Fig. $4 C$ ). The mice received a single footshock 7 weeks after injection of the virus and we evaluated fear recall $28 \mathrm{~d}$ later, as in previous experiments. Similar to PTH2R-KO mice, mice injected with lenti-HYWH had higher levels of freezing than lenti-GFP controls (Fig. $4 D$; Student's $t$ test, $T_{(15)}=$ $3.40, p=0.004 ; n=9$ for lenti-GFP, $n=8$ for lenti-HYWH). Therefore blockade of TIP39 signaling in the amygdala enhanced fear incubation. We also evaluated incubation effects on anxiety-related behaviors 1 and $2 \mathrm{~d}$ after fear recall testing using the light/dark box transition and elevated zero maze tests, respectively. There were no significant differences between lenti-GFP and lenti-HYWH in the light box duration (light/dark box transition test) or open area duration (elevated zero maze test), suggesting that blocking MeA TIP39 signaling does not affect anxiety-related behaviors (data not shown). The virusinfected cells were adjacent to or within the MeA, but a limitation in the interpretation of these data is that because the PTH2R antagonist is a secreted diffusible molecule, the region over which it acts cannot be precisely defined.

\section{Ablation of MeA PTH2R neurons enhances fear incubation} Since blockade of TIP39 signaling cannot be done with anatomical specificity, we next used a PTH2R-Cre mouse line to target neurons that express PTH2R. We first confirmed that the distribution of reporter-expressing neurons in the MeA and CeA following amygdalar injection of a virus with Cre-dependent expression of a fluorescent protein (AAV2/9.flex.arch) was consistent with PTH2R immunolabeling in the amygdala (Fig. $5 A$ ). We then examined the effect of ablating neurons that express PTH2Rs by taking advantage of the observation that normal mouse cells are resistant to diphtheria toxin. We injected an AAV that encodes Cre-dependent expression of the human diphtheria toxin receptor (AAV2.DTR) into the MeA of PTH2R-Cre male 
mice bilaterally, and administered diphtheria toxin (DTX) systemically 3 weeks after the virus injection to ablate the PTH2R-expressing neurons. The mice received a single footshock 3 weeks after DTX administration and fear recall was evaluated $28 \mathrm{~d}$ later, as in previous experiments. The freezing levels of PTH2Rneuron ablated mice (DTX-DTR) were significantly greater than virus-injected, saline-treated control mice (DTR-saline; Fig. $5 B$; Student's $t$ test, $T_{(8)}=2.52, p=$ 0.036; $n=4$ for DTR-saline, $n=6$ for DTR-DTX), localizing the fear enhancement effect to the loss of a population of $\mathrm{MeA}$ area neurons. Immunolabeling performed after the behavioral experiments confirmed the MeA localization of AAV2.DTR by showing an obvious reduction of PTH2R-ir in the PTH2R neuron ablated mice (Fig. $5 C, D$ ).

\section{Inhibition of MeA PTH2R neurons at the time of footshock enhances fear incubation}

We next used the designer receptor exclusively activated by designer drug (DRE$\mathrm{ADD})$ pharmacogenetic technique to examine whether inhibition of PTH2Rexpressing neurons in the MeA during the initial coding and/or recall of fear memory underlies the fear memory enhancement. We injected a Cre-dependent Gicoupled DREADD virus (hM4Di) that can suppress neuronal activity into the MeA of PTH2R-Cre male mice (Fig. 6A). In one group of hM4Di-expressing mice, we injected saline or CNO, a DREADD agonist that has no effect on endogenous receptors, $1 \mathrm{~h}$ before footshock and in another group of mice we injected $\mathrm{CNO}$ or saline $1 \mathrm{~h}$ before fear recall testing. We evaluated fear recall 1 and $28 \mathrm{~d}$ after footshock in mice administered $\mathrm{CNO}$ at the time of footshock and only at day 28 for mice administered $\mathrm{CNO}$ at the time of recall testing. Inhibiting PTH2R neurons with CNO at the time of shock increased freezing levels during fear recall at $28 \mathrm{~d}$ but not at $1 \mathrm{~d}$ compared with salinetreated mice (Fig. $6 \mathrm{~B}$; two-way repeated-measures ANOVA, $F_{\text {treatment }} \times$ time $(1,11)=6.11, p=0.029 ; n=6$ for saline, $n=8$ for CNO; Bonferroni post hoc test, $p<0.01$ ). This is consistent with the increased fear incubation effect we found in PTH2R-KO mice and suggests that PTH2R-expressing neurons in the MeA may be responsible for this stronger incubation effect. In this experiment, recall was tested in each animal at both 1 and $28 \mathrm{~d}$ after shock. The CNO-treated mice had a significant fear incubation effect but the saline-treated mice did not, which may be an effect of extinction caused by re-exposure to the shock context on day 1 . In contrast to the effect of PTH2R neuron inhibition at the time of footshock, inhibiting PTH2R neurons only at the time of recall testing had no effect on freezing behavior (Fig. 6C). CNO effects last several hours (Alexander et al., 2009) so administration of CNO $1 \mathrm{~h}$ before footshock does not allow discrimination between effects at the stages of acquisition and initial encoding of fear memory or its consolidation over the next few hours. To address this issue, we injected a separate cohort of MeA hM4Di-
B

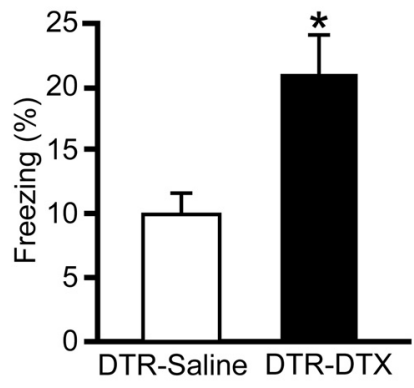

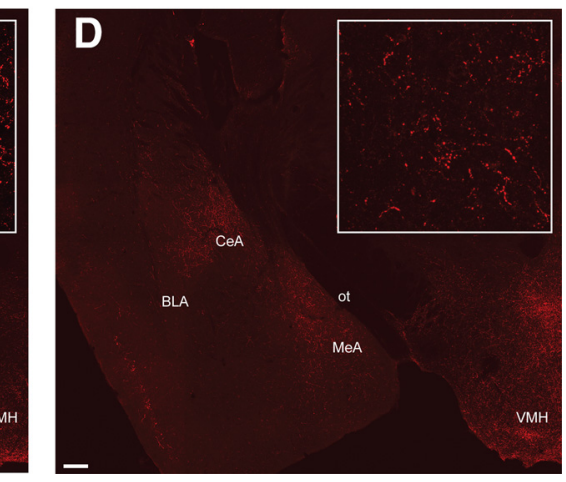
Figure 5. Ablation of PTH2R-expressing neurons in the MeA enhances fear incubation. $\boldsymbol{A}$, Cells that contain GFP following
MeA-targeted injection of AAV2/9.flex.arch show Cre-dependent reporter expression in PTH2R-cre mice. $\boldsymbol{B}$, Freezing responses during fear recall $28 \mathrm{~d}$ after footshock in control (DTR-Saline) and PTH2R neuron ablated mice (DTR-DTX). C, DTR-Saline mouse showing dense PTH2R expression in the MeA. D, DTR-DTX mouse showing a robust reduction of PTH2R expression in the MeA, MeA. Scale bars: $A, C, D, 200 \mu \mathrm{m}$. DTR-Saline: $n=4$; DTR-DTX: $n=6 .{ }^{*} p<0.05$ versus saline. BLA, basolateral amygdala; VMH, ventromedial nucleus of the hypothalamus; ot, optic tract.

expressing PTH2R-Cre mice with CNO immediately after footshock (within 3-4 min). Inhibition of PTH2R neurons after shock application increased freezing levels during fear recall measured at $28 \mathrm{~d}$ (Fig. $6 D$; Student's $t$ test, $T_{(6)}=3.179, p=0.019$; $n=4$ for saline, $n=4$ for $\mathrm{CNO}$ ). To examine whether the fear memory-enhancing effect of hM4Di-mediated inhibition was specific to the MeA PTH2R neurons, we also bilaterally injected the hM4Di virus into the CeA of PTH2R-cre mice (Fig. $6 E$ ). Inhibition of CeA PTH2R neurons at the time of shock did not affect freezing behavior either $1 \mathrm{~d}$ or $28 \mathrm{~d}$ after footshock (Fig. $6 F$ ). These results suggest that inhibition of the MeA population of PTH2R-expressing neurons just after exposure to the stressor robustly enhances memory for the footshock associated context.

\section{Extinction training reverses the fear incubation effects in PTH2R-KO mice}

Several lines of evidence described above suggest that TIP39 signaling has a significant role at the time of the encoding and/or consolidation of footshock-induced enhanced fear, but not at the time of its recall. We next asked whether extinction, another important part of the fear learning and memory process, is also influenced by TIP39 signaling. Shocked PTH2R-KO and WT mice were re-exposed to the shock context for 3 consecutive days, 30 min each day, starting $24 \mathrm{~h}$ after the footshock without receiving any additional shocks. Freezing responses to the shock con- 

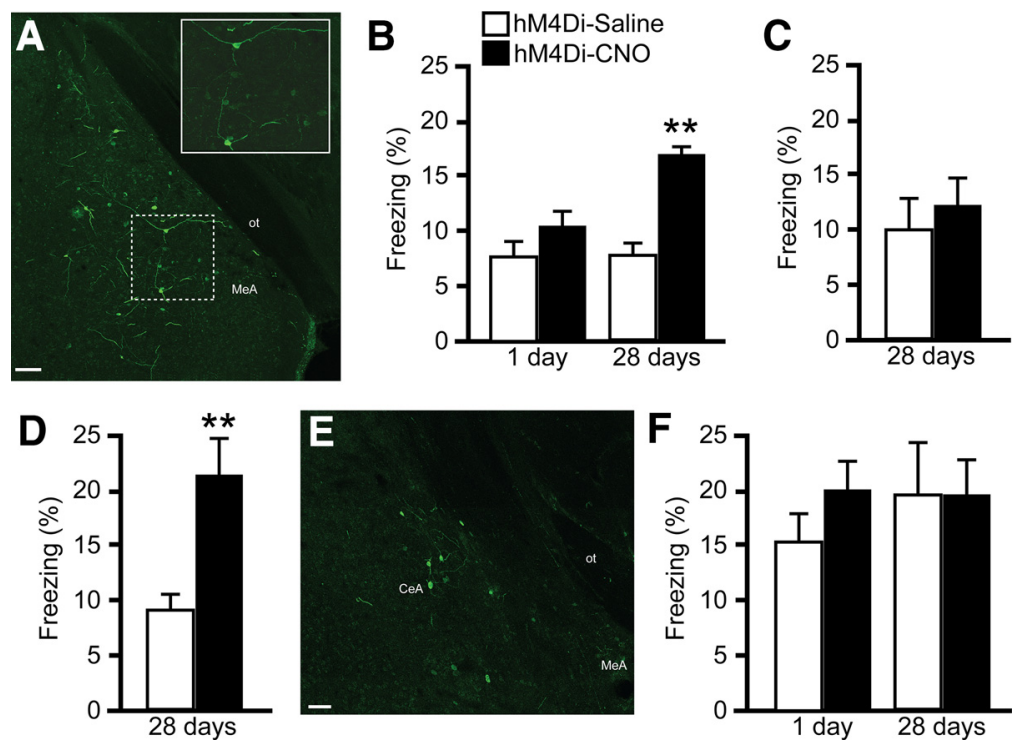

Figure 6. Inhibition of MeA PTH2R neurons near the time of footshock enhances fear incubation. $\boldsymbol{A}$, Labeling with an antibody to GFP shows virus-infected cells in the MeA of a PTH2R-cre mouse injected with a Cre-dependent Gi-coupled DREADD virus (hM4Di; the citrine epitope tag is recognized by the antibody to GFP). Inset, high-power view. PTH2R-cre mice injected with hM4Di were administered saline or CN0 $1 \mathrm{~h}$ before footshock $(\boldsymbol{B}), 1 \mathrm{~h}$ before fear recall testing $(\boldsymbol{C})$, or immediately after $(3-4 \mathrm{~min})$ footshock $(\boldsymbol{D})$. Fear recall was evaluated 1 and $28 \mathrm{~d}$ after shock in mice treated with CNO before footshock and only at 28 din mice treated with CNO after shock. Fear recall was only tested $28 \mathrm{~d}$ after shock for mice treated with CNO at that time. $\boldsymbol{E}$, Anti-GFP labeling of hM4Diinfected cells in the CeA of a CeA-targeted PTH2R-cre mouse. $\boldsymbol{F}$, Fear recall assessed 1 and $28 \mathrm{~d}$ after shock in PTH2R-cre mice injected with hM4Di into the CeA that were administered saline or CNO at the time of footshock. Scale bars: $\boldsymbol{A}, \boldsymbol{E}, 100 \mu \mathrm{m}$ hM4Di-MeA-at the time of shock: saline, $n=6$, CN0, $n=8$; hM4Di-MeA-at the time of fear recall: saline, $n=6$, CNO, $n=$ 6; hM4Di-MeA-after shock: saline, $n=4, \mathrm{CN} 0, n=4$; hM4Di-CeA-at the time of shock: saline, $n=8$, CN0, $n=8$. ${ }^{* *} p<$ 0.01 versus $h M 4 D i-s a l i n e$ at the same time point. $0 t$, optic tract,

A

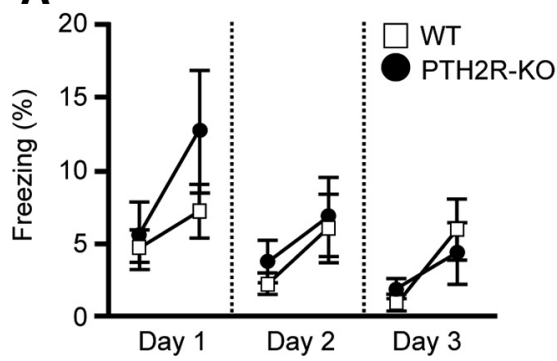

B

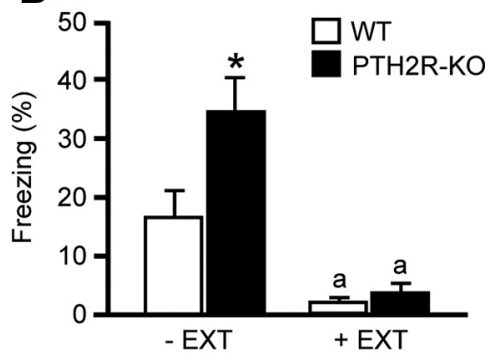

Figure 7. Effects of extinction training on fear incubation in WT and PTH2R-KO male mice. $\boldsymbol{A}$, Percentage of time spent freezing during re-exposure to the shock context on days 1-3 of extinction training. For each training day, the first and second data point represents the freezing responses measured during the first and last $3 \mathrm{~min}$, respectively, of the $30 \mathrm{~min}$ period. $\boldsymbol{B}$, Freezing responses of WT and PTH2R-KO mice with (+EXT) or without ( - EXT) extinction training during fear recall testing $28 \mathrm{~d}$ after footshock. -EXT:WT, $n=7$, PTH2R-K0, $n=6$; + EXT:WT, $n=7$, PTH2R-K0, $n=7 .{ }^{*} p<0.05$ versus WT of same treatment group; ${ }^{a} p<$ 0.05 versus - EXT group of same genotype.

text during the $3 \mathrm{~d}$ of extinction training decreased on successive days (Fig. $7 A$; two-way repeated ANOVA, $F_{\text {time }(5,55)}=8.00, p<$ $0.0001 ; n=6-7$ per group), indicating efficient extinction training. We then evaluated fear recall $28 \mathrm{~d}$ after the footshock. Consistent with previous experiments, PTH2R-KO mice without extinction training froze more than similarly treated WT mice (Fig. $7 B$; two-way ANOVA, $F_{\text {genotype } \times \text { treatment }(1,23)}=4.33, p=0.048$; Bonferroni post hoc test, $p<0.05)$. Extinction training robustly reduced freezing responses compared with mice without extinction training $\left(F_{\text {treatment }(1,23)}=33.05, p<0.0001\right)$ such that PTH2R-KO mice showed levels of freezing that were indistinguishable from similarly treated WT mice.

\section{Discussion}

Our major finding is that loss of signaling in the MeA either by the peptide TIP39 or by cells expressing its receptor, PTH2R, enhances fear expression 2-4 weeks later. Because inhibition of MeA PTH2R-expressing neurons at the time of footshock contributed to exaggerated fear recall 1 month later, the data suggest that signaling by the TIP39/ PTH2R system in the MeA at the time of aversive events may normally limit the longterm consequences.

Fear incubation is described as a timedependent increase in fear responses to fear-conditioned cues in the absence of additional stress or cue exposure (McAllister and McAllister, 1967). Fear incubation effects were described after $28 \mathrm{~d}$ in mice given a single footshock (Siegmund and Wotjak, 2006, 2007; Pamplona et al., 2011) or after $31 \mathrm{~d}$ in rats administered 10 tone-shock sessions (Pickens et al., 2009). Using the single footshock model, we observed that relative to similarly treated WT, PTH2R-KO mice displayed significantly greater freezing levels both 2 and 4 weeks after footshock while fear memory was similar to WT $1 \mathrm{~d}$ after footshock. These results support our previous findings that fear memory was not enhanced 1 week after footshock in either PTH2R-KO or TIP39-KO mice under conditions in which it was enhanced at 2 weeks (Coutellier and Usdin, 2011). Freezing levels in this study are lower than in some other studies that use C57BL/6J mice. Time of testing (dark phase) or scoring methods (manual) may have contributed to lower freezing. Fear conditioning was reported to be faster in the day than night and extinction was greater in mice trained during the night (Chaudhury and Colwell, 2002). Also, our definition of freezing was stricter than most automated systems. While generalization or sensitization is frequently associated with fear incubation, we did not observe an interaction between genotype and changes in either anxiety- or depression-related behavior outside of the training context. PTH2R is expressed in several brain regions involved in sensory information processing, but it is unlikely that differences in footshock perception are responsible for the fear enhancement. We previously reported that TIP39-KO do not differ from WT in the threshold for vocalization in response to footshock (Fegley et al., 2008) and in the present study, PTH2R-KO and WT mice displayed similar freezing levels immediately after footshock.

We refer to the increased freezing behavior in this study as enhanced fear incubation because of the relative increase observed several weeks after the footshock and its similarity to the phenomena described by others. TIP39 could potentially modulate fear incubation through PTH2Rs in several brain sites. While 
little is known about fear incubation mechanisms, the amygdala is likely to be important because of its key role in fear learning and memory. Recent studies show CeA involvement in another incubation phenomenon, incubation of drug craving (Pickens et al., 2011; Li et al., 2015), based on decreased cue-induced drugseeking behavior caused by CeA inactivation during late but not early withdrawal (Li et al., 2015). Within the amygdala, there are PTH2R-expressing cell bodies and fibers in the CeA and MeA, and not in the basolateral and lateral nuclei (Faber et al., 2007). We found that the number of c-Fos-positive cells did not increase in the MeA of PTH2R-KO mice following either footshock or recall testing as it did in $\mathrm{WT}$, whereas in the CeA c-Fos induction did not differ from WT. MeA processing of olfactory information that affects social behavior and defensive responses is well known. Recent studies also show a contribution to fear memory and anxiety-related behaviors (Milanovic et al., 1998; Walker et al., 2005; Takahashi et al., 2007; Trogrlic et al., 2011; Cousens et al., 2012; Vicentini et al., 2014; Yoshida et al., 2014). One investigation of lesion effects led to the suggestion that the MeA plays an important role in defensive reactions to uncertain, as opposed to imminent, threats (McCue et al., 2014). Other studies report robust activation of MeA immediate early gene expression by contextual fear conditioning (Milanovic et al., 1998; Trogrlic et al., 2011). Thus a difference in immediate early gene activation suggests that the MeA may be involved in fear-related differences between mice with or without TIP39 signaling. This was supported by results from three independent experimental approaches that localize effects of TIP39 signaling loss to the MeA: blockade of TIP39 signaling via localized expression of a receptor antagonist, ablation of PTH2R-expressing MeA neurons, and transient inhibition of PTH2R-expressing MeA neurons. Therefore normal TIP39 signaling via MeA PTH2R-expressing neurons lessens the expression of fear memory observed several weeks after an acute fearful event. To our knowledge this is the first study to reveal MeA involvement in fear incubation and memory for remote events.

The CeA is unlikely to be where TIP39 signaling affects fear incubation. In addition to the lack of difference in c-Fos induction between WT and PTH2R-KO mice, DREADD-mediated inhibition of CeA PTH2R-expressing cells did not affect fear incubation. However, the CeA might play an important role either upstream or downstream of the MeA. Other relevant brain regions from which the MeA receives input and/or to which it projects include the prefrontal cortex, hippocampus, basolateral amygdala, bed nucleus of the stria terminalis (BNST), dorsal premammillary body, and periaqueductal gray (LeDoux, 2000; Paré et al., 2004; Pardo-Bellver et al., 2012; Cádiz-Moretti et al., 2014). The BNST is of particular interest because it is densely innervated from the MeA and has a high density of PTH2R-expressing nerve fibers and terminals. PTSD-like behaviors and contextual fear memory freezing responses have also been associated with signaling in the BNST (Sullivan et al., 2004; Lebow et al., 2012; Elharrar et al., 2013).

TIP39 presumably acts as a neuromodulator to influence the state of MeA circuits that process footshock-derived information. There is precedent for neuromodulators having major effects on state-dependent memory (Marder et al., 2014), including fear learning (Reich et al., 2008). MeA TIP39 is provided by terminals of subparafascicular area neurons (Dobolyi et al., 2003a). Subparafascicular area inputs include a large number of sensory and integrative brain regions (Wang et al., 2006) making it quite reasonable that it influences the state of the MeA and modulates the consequences of fearful events, but not providing a strong indication of which inputs are relevant.

Enhanced fear incubation following inhibition of PTH2Rexpressing neurons at the time of footshock suggests that TIP39 signaling via MeA PTH2R neurons influences encoding or consolidation of memory for the fear-associated context. The observation that the effect of $\mathrm{CNO}$ administration just after footshock was similar to the effect of $\mathrm{CNO}$ administration before footshock favors the hypothesis that processes that occur in the hours just after the event (i.e., consolidation) are responsible for the effects of TIP39 signaling on fear behavior. The lack of DREADD activation effect during recall testing argues strongly against a significant contribution of MeA TIP39/PTH2R neuron signaling to modulation of fear memory retrieval. The current data suggest that the relevant effects of TIP39 signaling may occur in the hours after footshock but does not address any potential changes during the weeks between the footshock and measurement of fear behavior. Our prior data indicating that fear memory did not differ between WT and PTH2R-KO mice 1 week after footshock argues that the effect is not simply on consolidation (Coutellier and Usdin, 2011), but that TIP39 signaling modulates a process that requires an "incubation period" to develop.

Traumatic memories can be influenced by stress hormones. Fear-associated stimulation of adrenal glucocorticoid release is thought to contribute to enhanced fear memory in conditioning paradigms similar to that used in this study (de Quervain et al., 2009). Glucocorticoid dysregulation following a traumatic event is also thought to contribute to PTSD-like symptoms in animals and humans (Herman, 2013). PTH2R-KO mice had a significantly elevated corticosterone level 90 min after footshock, suggesting that increased HPA axis reactivity could contribute to the response. However, the fractional increase was not significantly different from that of WT mice. Enhanced fear incubation in PTH2R-KO mice was preserved after ADX, providing additional evidence that the effect of TIP39 signaling loss is not mediated through the HPA axis. It is unlikely that an effect mediated by regulation of low residual corticosterone production in ADX mice is responsible for the preserved fear incubation enhancement, because addition of a fixed dose of exogenous corticosterone that would overwhelm this production did not eliminate fear enhancement. The conclusion that the MeA regulates fear incubation independently of its effects on the HPA axis is consistent with the observation that the MeA does not regulate the HPA axis during chronic stress (Solomon et al., 2010).

In summary, we demonstrated that TIP39 signaling plays a role in fear incubation and suggest that physiologically it may serve to ameliorate the long-term negative outcome of traumatic experience via PTH2R-expressing neurons in the MeA. We also provide a mouse model, mice lacking TIP39 signaling, as a potential tool for examining how the long-term consequences of traumatic experiences, such as PTSD-like symptoms, develop.

\section{References}

Alexander GM, Rogan SC, Abbas AI, Armbruster BN, Pei Y, Allen JA, Nonneman RJ, Hartmann J, Moy SS, Nicolelis MA, McNamara JO, Roth BL (2009) Remote control of neuronal activity in transgenic mice expressing evolved $g$ protein-coupled receptors. Neuron 63:27-39. CrossRef Medline

Andrews B, Brewin CR, Philpott R, Stewart L (2007) Delayed-onset posttraumatic stress disorder: a systematic review of the evidence. Am J Psychiatry 164:1319-1326. CrossRef Medline

Cádiz-Moretti B, Otero-García M, Martínez-García F, Lanuza E (2014) Afferent projections to the different medial amygdala subdivisions: a retrograde tracing study in the mouse. Brain Struct Funct. Advance online publication. Retrieved April 21, 2015. doi: 10.1007/s00429-014-0954-y. 
Chaudhury D, Colwell CS (2002) Circadian modulation of learning and memory in fear-conditioned mice. Behav Brain Res 133:95-108. CrossRef Medline

Cousens GA, Kearns A, Laterza F, Tundidor J (2012) Excitotoxic lesions of the medial amygdala attenuate olfactory fear-potentiated startle and conditioned freezing behavior. Behav Brain Res 229:427-432. CrossRef Medline

Coutellier L, Usdin TB (2011) Enhanced long-term fear memory and increased anxiety and depression-like behavior after exposure to an aversive event in mice lacking TIP39 signaling. Behav Brain Res 222:265-269. CrossRef Medline

Coutellier L, Logemann A, Kuo J, Rusnak M, Usdin TB (2011) TIP39 modulates effects of novelty-induced arousal on memory. Genes Brain Behav 10:90-99. CrossRef Medline

de Quervain DJF, Aerni A, Schelling G, Roozendaal B (2009) Glucocorticoids and the regulation of memory in health and disease. Front Neuroendocrinol 30:358-370. CrossRef Medline

Dimitrov EL, Petrus E, Usdin TB (2010) Tuberoinfundibular peptide of 39 residues (TIP39) signaling modulates acute and tonic nociception. Exp Neurol 226:68-83. CrossRef Medline

Dimitrov EL, Kuo J, Kohno K, Usdin TB (2013) Neuropathic and inflammatory pain are modulated by tuberoinfundibular peptide of 39 residues. Proc Natl Acad Sci U S A 110:13156-13161. CrossRef Medline

Dobolyi A, Palkovits M, Bodnár I, Usdin TB (2003a) Neurons containing tuberoinfundibular peptide of 39 residues project to limbic, endocrine, auditory and spinal areas in rat. Neuroscience 122:1093-1105. CrossRef Medline

Dobolyi A, Palkovits M, Usdin TB (2003b) Expression and distribution of tuberoinfundibular peptide of 39 residues in the rat central nervous system. J Comp Neurol 455:547-566. CrossRef Medline

Dobolyi A, Palkovits M, Usdin TB (2010) The TIP39-PTH2 receptor system: unique peptidergic cell groups in the brainstem and their interactions with central regulatory mechanisms. Prog Neurobiol 90:29-59. CrossRef Medline

Elharrar E, Warhaftig G, Issler O, Sztainberg Y, Dikshtein Y, Zahut R, Redlus L, Chen A, Yadid G (2013) Overexpression of corticotropin-releasing factor receptor type 2 in the bed nucleus of stria terminalis improves posttraumatic stress disorder-like symptoms in a model of incubation of fear. Biol Psychiatry 74:827-836. CrossRef Medline

Faber CA, Dobolyi A, Sleeman M, Usdin TB (2007) Distribution of tuberoinfundibular peptide of 39 residues and its receptor, parathyroid hormone 2 receptor, in the mouse brain. J Comp Neurol 502:563-583. CrossRef Medline

Fegley DB, Holmes A, Riordan T, Faber CA, Weiss JR, Ma S, Batkai S, Pacher P, Dobolyi A, Murphy A, Sleeman MW, Usdin TB (2008) Increased fear- and stress-related anxiety-like behavior in mice lacking tuberoinfundibular peptide of 39 residues. Genes Brain Behav 7:933-942. CrossRef Medline

Herman JP (2013) Neural control of chronic stress adaptation. Front Behav Neurosci 7:61. CrossRef Medline

Herry C, Johansen JP (2014) Encoding of fear learning and memory in distributed neuronal circuits. Nat Neurosci 17:1644-1654. CrossRef Medline

Hopman AH, Ramaekers FC, Speel EJ (1998) Rapid synthesis of biotin-, digoxigenin-, trinitrophenyl-, and fluorochrome-labeled tyramides and their application for In situ hybridization using CARD amplification. J Histochem Cytochem 46:771-777. CrossRef Medline

Krashes MJ, Koda S, Ye C, Rogan SC, Adams AC, Cusher DS, Maratos-Flier E, Roth BL, Lowell BB (2011) Rapid, reversible activation of AgRP neurons drives feeding behavior in mice. J Clin Invest 121:1424-1428. CrossRef Medline

Kuo J, Usdin TB (2007) Development of a rat parathyroid hormone 2 receptor antagonist. Peptides 28:887-892. CrossRef Medline

LaBuda CJ, Dobolyi A, Usdin TB (2004) Tuberoinfundibular peptide of 39 residues produces anxiolytic and antidepressant actions. Neuroreport 15: 881-885. CrossRef Medline

Lebow M, Neufeld-Cohen A, Kuperman Y, Tsoory M, Gil S, Chen A (2012) Susceptibility to PTSD-like behavior is mediated by corticotropinreleasing factor receptor type 2 levels in the bed nucleus of the stria terminalis. J Neurosci 32:6906-6916. CrossRef Medline

LeDoux JE (2000) Emotion circuits in the brain. Annu Rev Neurosci 23: 155-184. CrossRef Medline

Li X, Zeric T, Kambhampati S, Bossert JM, Shaham Y (2015) The central amygdala nucleus is critical for incubation of methamphetamine craving. Neuropsychopharmacology 40:1297-1306. CrossRef Medline

Marder E, O'Leary T, Shruti S (2014) Neuromodulation of circuits with variable parameters: single neurons and small circuits reveal principles of state-dependent and robust neuromodulation. Annu Rev Neurosci 37: 329-346. CrossRef Medline
Marek R, Strobel C, Bredy TW, Sah P (2013) The amygdala and medial prefrontal cortex: partners in the fear circuit. J Physiol 591:2381-2391. CrossRef Medline

McAllister DE, McAllister WR (1967) Incubation of fear: an examination of the concept. J Exp Res Personality 2:180-190.

McCue MG, LeDoux JE, Cain CK (2014) Medial amygdala lesions selectively block aversive pavlovian-instrumental transfer in rats. Front Behav Neurosci 8:329. Medline

Milanovic S, Radulovic J, Laban O, Stiedl O, Henn F, Spiess J (1998) Production of the Fos protein after contextual fear conditioning of C57BL/6N mice. Brain Res 784:37-47. CrossRef Medline

Morrow JD, Saunders BT, Maren S, Robinson TE (2015) Sign-tracking to an appetitive cue predicts incubation of conditioned fear in rats. Behav Brain Res 276:59-66. CrossRef Medline

Müller M, Fendt M (2006) Temporary inactivation of the medial and basolateral amygdala differentially affects TMT-induced fear behavior in rats. Behav Brain Res 167:57-62. CrossRef Medline

Palkovits M, Helfferich F, Dobolyi A, Usdin TB (2009) Acoustic stress activates tuberoinfundibular peptide of 39 residues neurons in the rat brain. Brain Struct Funct 214:15-23. CrossRef Medline

Pamplona FA, Henes K, Micale V, Mauch CP, Takahashi RN, Wotjak CT (2011) Prolonged fear incubation leads to generalized avoidance behavior in mice. J Psychiatr Res 45:354-360. CrossRef Medline

Pardo-Bellver C, Cádiz-Moretti B, Novejarque A, Martínez-García F, Lanuza E (2012) Differential efferent projections of the anterior, posteroventral, and posterodorsal subdivisions of the medial amygdala in mice. Front Neuroanat 6:33. CrossRef Medline

Paré D, Quirk GJ, Ledoux JE (2004) New vistas on amygdala networks in conditioned fear. J Neurophysiol 92:1-9. CrossRef Medline

Paxinos G, Franklin KBJ (2008) The mouse brain in stereotaxic coordinates. San Diego: Elsevier Academic.

Pickens CL, Golden SA, Adams-Deutsch T, Nair SG, Shaham Y (2009) Long-lasting incubation of conditioned fear in rats. Biol Psychiatry 65: 881-886. CrossRef Medline

Pickens CL, Airavaara M, Theberge F, Fanous S, Hope BT, Shaham Y (2011) Neurobiology of the incubation of drug craving. Trends Neurosci 34:411420. CrossRef Medline

Reich CG, Mohammadi MH, Alger BE (2008) Endocannabinoid modulation of fear responses: learning and state-dependent performance effects. J Psychopharmacol 22:769-777. CrossRef Medline

Siegmund A, Wotjak CT (2006) Toward an animal model of posttraumatic stress disorder. Ann N Y Acad Sci 1071:324-334. CrossRef Medline

Siegmund A, Wotjak CT (2007) A mouse model of posttraumatic stress disorder that distinguishes between conditioned and sensitised fear. J Psychiatr Res 41:848-860. CrossRef Medline

Solomon MB, Jones K, Packard BA, Herman JP (2010) The medial amygdala modulates body weight but not neuroendocrine responses to chronic stress. J Neuroendocrinol 22:13-23. CrossRef Medline

Sullivan GM, Apergis J, Bush DE, Johnson LR, Hou M, Ledoux JE (2004) Lesions in the bed nucleus of the stria terminalis disrupt corticosterone and freezing responses elicited by a contextual but not by a specific cueconditioned fear stimulus. Neuroscience 128:7-14. CrossRef Medline

Takahashi LK, Hubbard DT, Lee I, Dar Y, Sipes SM (2007) Predator odorinduced conditioned fear involves the basolateral and medial amygdala. Behav Neurosci 121:100-110. CrossRef Medline

Trogrlic L, Wilson YM, Newman AG, Murphy M (2011) Context fear learning specifically activates distinct populations of neurons in amygdala and hypothalamus. Learn Mem 18:678-687. CrossRef Medline

Vicentini JE, Céspedes IC, Nascimento JO, Bittencourt JC, Viana MB (2014) CRF type 1 receptors of the medial amygdala modulate inhibitory avoidance responses in the elevated T-maze. Horm Behav 65:195-202. CrossRef Medline

Walker DL, Paschall GY, Davis M (2005) Glutamate receptor antagonist infusions into the basolateral and medial amygdala reveal differential contributions to olfactory versus context fear conditioning and expression. Learn Mem 12:120-129. CrossRef Medline

Wang J, Palkovits M, Usdin TB, Dobolyi A (2006) Afferent connections of the subparafascicular area in rat. Neuroscience 138:197-220. CrossRef Medline

Yoshida M, Takayanagi Y, Onaka T (2014) The medial amygdala-medullary PrRP-synthesizing neuron pathway mediates neuroendocrine responses to contextual conditioned fear in male rodents. Endocrinology 155:29963004. CrossRef Medline 